The Bangladesh Veterinarian (2015) 32(2): 65 - 72

\title{
Factors influencing the rates of pregnancy, calving and peri- parturient disorders in heifers at selected char areas of Bangladesh
}

MM Hossain, MMU Bhuiyan*, MM Rahman and NS Juyena

Department of Surgery and Obstetrics, Faculty of Veterinary Science, Bangladesh Agricultural University, Mymensingh-2202, Bangladesh

\begin{abstract}
The study was conducted to evaluate the factors affecting the rates of pregnancy, calving and peri-parturient disorders in heifers in selected char areas (low lying flood and erosionprone areas in or adjacent to major rivers) of Lalmonirhat district of Bangladesh. A total of 101 artificial inseminated (AI) heifers were randomly selected for monitoring rates of pregnancy, calving and peri-parturient disorders with respect to breed of semen, source of semen, breed, age, body weight and body condition score (BCS) of heifers. The overall rates of pregnancy, calving and peri-parturient disorder were $51.5 \%, 45.5 \%$ and $32.6 \%$, respectively. The differences were not significant with respect to the factors evaluated (P>0.05). (Bangl. vet. 2015. Vol. 32, No. 2, 65 - 72)
\end{abstract}

\section{Introduction}

Dairy cows play an important role in the livelihood of poor and marginal farmers in Char (low lying flood and erosion-prone areas in or adjacent to major rivers; Howes, 2006) area of Bangladesh. Dairy cattle farming and management in the mainland is convenient due to facilities such as feed, drugs and veterinary services as well as marketing. Cows in chars, however, lack these facilities, and suffer more from health and fertility problems. Most cattle of char areas are local zebu producing 0.5 to 1.5 litres of milk per day. For increasing milk yield, crossbreeding through AI using semen of exotic breeds is beneficial.

AI has been introduced since early 1960s for upgrading local cows (Ahmed and Islam, 1987). However, the achievement of AI in Bangladesh is still unsatisfactory. The success of any AI programme may be influenced by many factors (Siddiqui et al., 2012; Mollah et al., 2015). An inefficient AI programme not only causes reduced rates of pregnancy and calving but also causes economic loss. Limited investigations have been conducted on success of AI programmes in char areas of Bangladesh (Paul et al., 2011). The present study was conducted to evaluate factors affecting the rates of pregnancy, calving and peri-parturient disorders in heifers received AI.

*Corresponding author:- E-mail: mmubhuiyan@gmail.com 


\section{Materials and Methods}

\section{Study area and period}

This study was conducted from January 2012 to May 2013 at the Khogar char of Bhadoi and Bolder char of Mahiskhocha Union in Aditmari Upazila (Sub-district) of Lalmonirhat district of Bangladesh.

\section{Animal selection and management}

A total of 101 heifers (75 local zebus and 26 crossbred) were randomly selected. All heifers had been donated to the ultra-poor farmers by the Char Livelihood Programme (CLP) in Bangladesh. They were treated against round worms and liver fluke, and vaccinated against foot and mouth disease, anthrax and haemorrhagic septicaemia. All heifers were housed about 18 hours in their rearing sheds with natural ventilation. The animals were fed with concentrate, green grass (cut and carried) and straw with free access to drinking water. The animals grazed from early morning to noon and fed with 4-6 $\mathrm{kg}$ green grass mixed with 2-3 $\mathrm{kg}$ straw daily as evening meal. In addition, some farmers fed $150 \mathrm{~g}$ mixed concentrate (rice polish, wheat bran, broken rice and oil cake) per animal twice daily.

\section{Determination of age, body weight and body condition score (BCS) of heifers}

Age of heifers was estimated by observing teeth. Body weight of heifers was estimated by using a measuring tape using the following formula:

Body weight $=\left\{\left(\mathrm{L} \times \mathrm{G}^{2}\right) / 300\right\} / 2.2 \mathrm{~kg}$

Where $L=$ Length from point of shoulder to point of pin bone in inches, $G=$ chest girth in inches.

Body condition score (BCS) was assessed by visual and tactile appraisal. A scoring system from 1 to 5 with 0.5 fractions was used.

\section{Oestrus detection, AI and pregnancy diagnosis}

Oestrus was detected by the farmers on the basis of oestrus signs and AI was performed by a trained technician using frozen semen. The semen was derived from bulls of Central Cattle Breeding Station (CCBS), Savar, Dhaka (DLS) or bulls of Bangladesh Rural Advancement Committee (BRAC), Shambuganj, Mymensingh. Pregnancy was diagnosed 60-90 days after AI by rectal palpation.

\section{Recording of AI, pregnancy, calving and peri-parturient disorders}

Immediately after AI, farmers' name and address, date of AI, breed of heifer, source of semen, age, body weight and BCS of heifer were recorded. Results of pregnancy diagnosis, calving and disorders in and around parturition were recorded. 


\section{Statistical analysis of data}

The data were entered in Microsoft Excel Worksheet and presented as percentages. The rates of pregnancy, calving and peri-parturient disorders were compared with respect to breed of bull (Sahiwal or Friesian), sources of semen (DLS vs. BRAC), breed (Local zebu vs. cross), age (24-29 vs. 30-35 vs. 36-42 months), body weight (120-160 vs. $161-200$ vs. $201-245 \mathrm{~kg}$ ) and BCS (2.0 vs. $2.5-3.0$ vs. $3.0-3.5)$ of heifers. The data were analysed by Chi-square test using SPSS software version 17 . The variation was considered significant when the P value was less than 0.05 .

\section{Results and Discussion}

The overall rates of pregnancy, calving and reproductive disorders in heifers of char areas were $51.5 \%$ (52/101 heifers), 45.5\% (46/101 heifers) and 32.6\% (15/46 parturient heifers), respectively. Similar pregnancy rate was reported by Al-Hasan (2003) in Friesian herds in Saudi Arabia and by Khatun et al. (2014) in Kurigram district of Bangladesh. Contrasting with the present finding, lower pregnancy rate (46.2) was reported in cattle of plain land by Shamsuddin et al. (2001) and of char areas $(43.8 \%)$ of Bangladesh by Islam (2015). Moreover, higher pregnancy rate (57.3\%) was reported in cattle of char areas of Sirajgonj district by Paul et al. (2011). The variation in pregnancy rates between studies might be due to variations in management of cows, skill of AI technicians and agro-ecological conditions of study areas.

\section{Effects of breed of bulls on rates of pregnancy, calving and peri-parturient disorders}

Effects of breed of bull on rates of pregnancy, calving and peri-parturient disorders are presented in Table 1 . The pregnancy rate was higher $(54.1 \%)$ when Sahiwal bull's semen was used for AI than with Friesian bulls (47.5\%). The calving rate was higher $(49.9 \%)$ when Sahiwal bull semen was used for AI than with Friesian bulls (35.2\%). The peri-parturient disorder rate was higher $(50.0 \%)$ when Friesian bull semen was used than with Sahiwal bulls (23.5\%). However, these differences were not significant $(\mathrm{P}>0.05)$. Similarly, higher pregnancy rate was observed in cows receiving Sahiwal semen than that of Friesian in Sirajgonj district (Paul et al., 2011). Contrasting with the present finding, the pregnancy rate in cows receiving Friesian semen was higher than that of Sahiwal bull semen in Gaibandha district (Mollah et al., 2015). Additionally, higher pregnancy rate was found in cows using Friesian semen than Sahiwal (Shamsuddin et al., 2001). The differences between studies might be due to variations in management of cows, skill of AI technicians, quality of semen and agro-ecological conditions of study areas. In the present study, higher rate of peri-parturient disorders in heifers receiving semen from Friesian than from Sahiwal bull may be explained by the greater size of foetus of Friesian cross compared with Sahiwal. Only bulls whose calves have acceptable birth weight should be considered for AI in heifers, since birth weight is the most significant factor affecting parturition. 
Table 1. Effects of breed of bull on rates of pregnancy, calving and peri-parturient disorders

\begin{tabular}{l|c|c|c|c|c|c|c}
\hline $\begin{array}{c}\text { Breed of } \\
\text { bulls }\end{array}$ & $\begin{array}{c}\text { No. of } \\
\text { inseminated } \\
\text { heifers }\end{array}$ & $\begin{array}{c}\text { No. of } \\
\text { pregnant } \\
\text { heifers }\end{array}$ & $\begin{array}{c}\text { Pregnancy } \\
\text { rate (\%) }\end{array}$ & $\begin{array}{c}\text { No. of } \\
\text { calves } \\
\text { born }\end{array}$ & $\begin{array}{c}\text { Calving } \\
\text { rate (\%) }\end{array}$ & $\begin{array}{c}\text { No. of heifers } \\
\text { with peri- } \\
\text { parturient } \\
\text { disorder }\end{array}$ & $\begin{array}{c}\text { Peri-parturient } \\
\text { disorder rate } \\
(\%)\end{array}$ \\
\hline Sahiwal & 61 & 33 & 54.1 & 30 & 49.9 & 8 & 23.5 \\
Friesian & 40 & 19 & 47.5 & 14 & 35.2 & 7 & 50.0 \\
\hline
\end{tabular}

The rates of pregnancy, calving and peri-parturient disorders within same column did not differ significantly from each other $(\mathrm{P}>0.05)$.

\section{Effects of source of semen on rates of pregnancy, calving and peri-parturient disorders}

Effects of source of semen on rates of pregnancy, calving and peri-parturient disorders are presented in Table 2 . The pregnancy rate was higher $(58.5 \%)$ when BRAC-derived semen was used compared to semen from DLS (46.7\%). The calving rate was higher $(48.9 \%)$ when BRAC semen was used compared to DLS $(41.7 \%)$. The peri-parturient disorder rate was higher $(35.0 \%)$ when BRAC semen was used compared to DLS (32.0\%). However, these differences were not significant $(\mathrm{P}>0.05)$. The present finding is consistent with other investigators where cows inseminated with frozen semen derived from BRAC showed higher $(61.6 \%)$ pregnancy rate than that of semen derived from DLS (55.0\%) (Shikder, 2011). The reason for lower pregnancy rate in heifers inseminated with DLS derived semen may be that the quality of semen of DLS might be inferior. The reason for higher peri-parturient disorders in heifers receiving semen from BRAC may be that the selection procedure of bulls might by better in DLS.

Table 2. Effects of source of semen on rates of pregnancy, calving and peri-parturient disorders

\begin{tabular}{l|c|c|c|c|c|c|c}
\hline $\begin{array}{c}\text { Sources } \\
\text { of } \\
\text { semen }\end{array}$ & $\begin{array}{c}\text { No. of } \\
\text { inseminated } \\
\text { heifers }\end{array}$ & $\begin{array}{c}\text { No. of } \\
\text { pregnant } \\
\text { heifers }\end{array}$ & $\begin{array}{c}\text { Pregnancy } \\
\text { rate (\%) }\end{array}$ & $\begin{array}{c}\text { No. of } \\
\text { calves } \\
\text { born }\end{array}$ & $\begin{array}{c}\text { Calving } \\
\text { rate (\%) }\end{array}$ & $\begin{array}{c}\text { No. of heifers } \\
\text { with peri- } \\
\text { parturient } \\
\text { disorder }\end{array}$ & $\begin{array}{c}\text { Peri- } \\
\text { parturient } \\
\text { disorder rate } \\
(\%)\end{array}$ \\
\hline DLS & 60 & 28 & 46.7 & 25 & 41.7 & 8 & 32.0 \\
BRAC & 41 & 24 & 58.5 & 20 & 48.9 & 7 & 35.0 \\
\hline
\end{tabular}

The rates of pregnancy, calving and peri-parturient disorder within same column did not differ significantly $(\mathrm{P}>0.05) ;$ DLS $=$ Department of Livestock Services, BRAC = Bangladesh Rural Advancement Committee

\section{Effects of breeds of heifers on rates of pregnancy, calving and peri-parturient disorders}

Effects of breed of heifer on rates of pregnancy, calving and peri-parturient disorders are presented in Table 3. The pregnancy rate was higher $(52.0 \%)$ in local heifers than in crossbred heifers $(50.0 \%)$. The calving rate was higher $(46.7 \%)$ in local heifers than 
in crossbred heifers (42.3\%). The peri-parturient disorder rate was higher $(36.4 \%)$ in crossbred heifers than in local heifers (31.5\%). However, these differences were not significant $(\mathrm{P}>0.05)$. Similarly, higher pregnancy rate was reported in local cows than in crossbred cows in char area of Sirajgonj district (Paul et al., 2011). Moreover, Khatun et al. (2014) obtained higher pregnancy rate in local cows than in Friesian and Sahiwal cross cows in Kurigram district. Contrasting with the present finding, Sarder et al. (2001) found better pregnancy rates in crossbred cows than in local counterparts in Rajshahi district. The reason for variations in pregnancy rates between studies might be variations in management of cows, skill of AI technicians, quality of semen and agro-ecological conditions of study areas.

Table 3. Effects of breeds of heifers on rates of pregnancy, calving and peri-parturient disorders

\begin{tabular}{l|c|c|c|c|c|c|c}
\hline $\begin{array}{c}\text { Breed } \\
\text { of } \\
\text { heifers }\end{array}$ & $\begin{array}{c}\text { No. of } \\
\text { inseminated } \\
\text { heifers }\end{array}$ & $\begin{array}{c}\text { No. of } \\
\text { pregnant } \\
\text { heifers }\end{array}$ & $\begin{array}{c}\text { Pregnancy } \\
\text { rate (\%) }\end{array}$ & $\begin{array}{c}\text { No. of } \\
\text { calves } \\
\text { born }\end{array}$ & $\begin{array}{c}\text { Calving } \\
\text { rate (\%) }\end{array}$ & $\begin{array}{c}\text { No. of heifers } \\
\text { with peri- } \\
\text { parturient } \\
\text { disorder }\end{array}$ & $\begin{array}{c}\text { Peri- } \\
\text { parturient } \\
\text { disorder rate } \\
(\%)\end{array}$ \\
\hline Local & 75 & 39 & 52.0 & 35 & 46.7 & 11 & 31.5 \\
Cross & 26 & 13 & 50.0 & 11 & 42.3 & 4 & 36.4 \\
\hline
\end{tabular}

The rates of pregnancy, calving and peri-parturient disorder within same column did not differ significantly $(\mathrm{P}>0.05)$.

\section{Effects of age of heifers on rates of pregnancy, calving and peri-parturient disorders}

Effects of age of heifers on rates of pregnancy, calving and peri-parturient disorders are presented in Table 4 . The pregnancy rate was the highest (66.7\%) in 36-42 monthold heifers and the lowest $(40.0 \%)$ at $24-29$ months. The calving rate was the highest $(57.0 \%)$ in 36-42 month-old heifers and the lowest (36.7\%) at 24-29 months. The periparturient disorder rate was the highest (36.4\%) in 24-29 month-old heifers and the lowest (26.3\%) at 36-42 months old counterparts. However, the differences were not significant $(\mathrm{P}>0.05)$. Similarly, no significant difference was obtained in pregnancy rate with respect to age of cows in Sirajgonj district (Paul et al., 2011). Contrasting with the present finding, variation in pregnancy rate was reported with respect to age of cows in Gaibandha district (Mollah et al., 2015). Analysing data from Botswana, Buck et al. (1976) found that fertility rate increased from $69 \%$ in 2.5-year-old cows to a maximum of $82 \%$ in 6- to 7 -year-old cows and then declined. In Bolivia, Plasse et al. (1975) recorded an increase in pregnancy rate from 50\% in 3-year-old purebred Criollo and Criollo $\times$ zebu cows to $75 \%$ in 7 -year-olds. Moreover, similar higher rate of periparturient disorders in younger heifers has been documented (Ahmed et al., 2005; Majed et al., 2009). This may be due to smaller pelvis in younger heifers.

\section{Effects of body weight of heifers on rates of pregnancy, calving and peri-parturient disorders}

Effects of body weight of heifers on rates of pregnancy, calving and peri-parturient disorders are presented in Table 5. The pregnancy rate was the highest $(53.8 \%)$ in 
heifers of $201-245 \mathrm{~kg}$ body weight and the lowest (46.6\%) in heifers of $120-160 \mathrm{~kg}$. The calving rate was the highest $(50.0 \%)$ in heifers of $201-245 \mathrm{~kg}$ body weight and the lowest $(36.7 \%)$ in heifers of $120-160 \mathrm{~kg}$. The rate of peri-parturient disorder was higher $(45.4 \%)$ in heifers of $120-160 \mathrm{~kg}$ body weight and lower $(23.1 \%)$ in heifers of 201-245 $\mathrm{kg}$. However, the differences were not significant $(\mathrm{P}>0.05)$. The pregnancy rate was higher in cows above $200 \mathrm{~kg}$ body weight than in lighter cows (Shikder, 2011). Moreover, there is a report that body weight of cows significantly affects the pregnancy rate in Kurigram district (Khatun et al., 2014). On the contrary, no significant effect of body weight of cows on pregnancy rate was found in Sirajgonj district (Paul et al., 2011). Higher rate of peri-parturient disorders was reported in cows with lower body weight than in heavier cows in Savar Dairy Farm, Dhaka (Majed et al., 2009).

Table 4. Effects of age of heifers on rates of pregnancy, calving and peri-parturient disorders

\begin{tabular}{l|c|c|c|c|c|c|c}
\hline $\begin{array}{c}\text { Age of } \\
\text { cows } \\
\text { (months) }\end{array}$ & $\begin{array}{c}\text { No. of } \\
\text { inseminated } \\
\text { heifers }\end{array}$ & $\begin{array}{c}\text { No. of } \\
\text { pregnant } \\
\text { heifers }\end{array}$ & $\begin{array}{c}\text { Pregnancy } \\
\text { rate (\%) }\end{array}$ & $\begin{array}{c}\text { No. of } \\
\text { calves } \\
\text { born }\end{array}$ & $\begin{array}{c}\text { Calving } \\
\text { rate (\%) }\end{array}$ & $\begin{array}{c}\text { No. of Heifers } \\
\text { with peri- } \\
\text { parturient } \\
\text { disorder }\end{array}$ & $\begin{array}{c}\text { Peri- } \\
\text { parturient } \\
\text { disorder rate } \\
(\%)\end{array}$ \\
\hline $24-29$ & 30 & 12 & 40.0 & 11 & 36.7 & 4 & 36.4 \\
$30-35$ & 38 & 18 & 47.0 & 16 & 42.5 & 6 & 31.5 \\
$36-42$ & 33 & 22 & 66.7 & 19 & 57.0 & 5 & 26.3 \\
\hline
\end{tabular}

The rates of pregnancy, calving and peri-parturient disorder within same column did not differ significantly $(\mathrm{P}>0.05)$

Table 5. Effects of body weight of heifers on rates of pregnancy, calving and periparturient disorders

\begin{tabular}{c|c|c|c|c|c|c|c}
\hline $\begin{array}{c}\text { Body } \\
\text { weight of } \\
\text { cows (kg) }\end{array}$ & $\begin{array}{c}\text { No. of } \\
\text { inseminated } \\
\text { heifers }\end{array}$ & $\begin{array}{c}\text { No. of } \\
\text { pregnant } \\
\text { heifers }\end{array}$ & $\begin{array}{c}\text { Pregnancy } \\
\text { rate (\%) }\end{array}$ & $\begin{array}{c}\text { No. of } \\
\text { calves } \\
\text { born }\end{array}$ & $\begin{array}{c}\text { Calving } \\
\text { rate (\%) }\end{array}$ & $\begin{array}{c}\text { No. of heifers } \\
\text { with peri- } \\
\text { parturient } \\
\text { disorder }\end{array}$ & $\begin{array}{c}\text { Peri- } \\
\text { parturient } \\
\text { disorder } \\
\text { rate }(\%)\end{array}$ \\
\hline $120-160$ & 30 & 14 & 46.6 & 11 & 36.7 & 5 & 45.4 \\
$161-200$ & 45 & 24 & 53.3 & 22 & 48.4 & 7 & 31.8 \\
$201-245$ & 26 & 14 & 53.8 & 13 & 50.0 & 3 & 23.1 \\
\hline
\end{tabular}

The rates of pregnancy, calving and peri-parturient disorder within same column did not differ significantly $(\mathrm{P}>0.05)$

\section{Effects of BCS on rates of pregnancy, calving and peri-parturient disorders}

Effects of BCS of heifers on rates of pregnancy, calving and peri-parturient disorders are presented in Table 6 . The pregnancy rate was the highest $(53.8 \%)$ in heifers with 3.0-3.5 BCS and the lowest (48.5\%) in heifers with 2.0 BCS. The calving rate was the highest $(50.0 \%)$ in heifers with 3.0-3.5 BCS and the lowest $(42.9 \%)$ in heifers with 2.0 
BCS. The peri-parturient disorder rate was the highest $(40.0 \%)$ in heifers with 2.0 BCS and the lowest $(23.1 \%)$ in heifers with 3.0-3.5 BCS. However, the differences were not significant among heifers with different $\mathrm{BCS}(\mathrm{P}>0.05)$. Higher pregnancy rate in cows with good BCS has been documented elsewhere in Bangladesh (Shamsuddin et al., 2001). An increased rate of peri-parturient disorders with decreased BCS of heifers has also been reported (Majed et al. 2009).

Table 6. Effects of body condition score on rates of pregnancy, calving and periparturient disorders

\begin{tabular}{l|c|c|c|c|c|c|c}
\hline BCS & $\begin{array}{c}\text { No. of } \\
\text { inseminated } \\
\text { heifers }\end{array}$ & $\begin{array}{c}\text { No. of } \\
\text { pregnant } \\
\text { heifers }\end{array}$ & $\begin{array}{c}\text { Pregnancy } \\
\text { rate (\%) }\end{array}$ & $\begin{array}{c}\text { No. of } \\
\text { calves } \\
\text { born }\end{array}$ & $\begin{array}{c}\text { Calving } \\
\text { rate }(\%)\end{array}$ & $\begin{array}{c}\text { No. of heifers } \\
\text { with peri- } \\
\text { parturient } \\
\text { disorder }\end{array}$ & $\begin{array}{c}\text { Peri- } \\
\text { parturient } \\
\text { disorder rate } \\
(\%)\end{array}$ \\
\hline 2.0 & 35 & 17 & 48.5 & 15 & 42.9 & 6 & 40.0 \\
2.5 & 40 & 21 & 52.5 & 18 & 45.0 & 6 & 33.3 \\
$3.0-3.5$ & 26 & 14 & 53.8 & 13 & 50.0 & 3 & 23.1 \\
\hline
\end{tabular}

The rates of pregnancy, calving and peri-parturient disorder within same column did not differ significantly $(\mathrm{P}>0.05)$

\section{Conclusions}

The overall rates of pregnancy, calving and peri-parturient disorders were $51.5 \%$, $45.5 \%$ and $32.6 \%$, respectively at selected char areas of Bangladesh. The rates did not differ significantly with age, body weight, body condition score, or source of semen.

\section{References}

Ahmed WM, El-Ekhnawy KI, El-Nattat WS, Desouky HM, Abd El-Razik KA, ElKhadrawy HH 2005: Investigations on calving associated problems in a Friesian herd in Egypt with special reference to some prophylactic trials. Egyptian Journal of Basic and Applied Physiology 3 65-87.

Ahmed Z, Islam TS 1987: Cattle breeding program through artificial insemination in Bangladesh. AI Extension Project Report, Central Cattle Breeding Station, Savar, Dhaka, Bangladesh.

Buck NG, light D, Rutherford A, Miller M, Prachctt TW, Capper B, Trail JCM 1976: Environmental factors affecting beef cow reproductive performance in Botswana. Animal Production 23 357-363.

Al-Hasan MJ 2003: Assessment of the reproductive performance of a Holstein dairy herd as affected by the efficiency of the inseminator. Journal of King Soud University Agricultural Science 15 79-88.

Howes M 2006: An introduction to the Char Livelihood Programme. CLP Secretariat, Rural Development Academy (RDA) Campus, Bogra, Bangladesh. 
Khatun MA, Bari FY, Alam MS, Ali MR, Sarker PK 2014: Post artificial insemination conception rate in cattle at Rajarhat, Kurigram. Wayamba Journal of Animal Science 6 845-854.

Islam MF 2015: Herd health management and livelihood of farmers living in char areas of Northern Bangladesh. PhD Dissertation, Department of Surgery and Obstetrics, Bangladesh Agricultural University, Mymensingh, Bangladesh. pp. 1-184.

Majed AF, Aboud QM, Hassan MS, Muhammad AY 2009: Retained foetal membranes in Holstein-Friesian cows and effect of some treatment methods. Iraqi Journal of Veterinary Science 23 5-8.

Mollah MFK, Gofur MR, Asaduzzaman KM, Bhuiyan MMU 2015: Conception rate of nondescript zebu cows and its attributing factors in Bangladesh. Research Journal of Veterinary Sciences 8 42-51.

Paul AK, Shamsuddin M, Alam MGS 2011: Factors that limit first service pregnancy rate in cows. Livestock Research for Rural Development 23 (Article \# 57).

Plasse D, Baver B, Verde O, Aragunde M 1975: Genetic and environmental effects on the reproductive efficiency of Criollo and zebu cows and their crosses. Memoria, Asociacion Latinoamericana de Produccion Animal 10 157-174.

Sarder MJU, Shamsuddin M, Bhuiyan MMU, Rahman MA 1997: Reproductive and productive performance of indigenous cows. Bangladesh Veterinary Journal 31 123-129.

Siddiqui MAR, Das ZC, Bhattacharjee J, Rahman, MM, Islam MM, Haque MA, Parish JJ, Shamsuddin M 2012: Factors affecting the first service conception rate of cows in smallholder dairy farms in Bangladesh. Reproduction in Domestic Animals 48 500-505.

Shikder A 2011: Post AI Pregnancy rate of crossbred and zebu cattle using frozen semen at Debhata and Kaligonj Upazilla in Satkhira district. MS in Theriogenology Thesis. Department of Surgery and Obstetrics, Faculty of Veterinary Science, Bangladesh Agricultural University, Mymensingh.

Shamsuddin M, Bhuiyan, MMU, Sikder TK, Sugulle AH, Chanda PK, Alam MGS, Galloway D 2001: Constraints limiting the efficiency of artificial insemination of cattle in Bangladesh. In: Radioimmunoassay and related techniques to improve artificial insemination programmes for cattle reared under tropical and subtropical conditions. IAEA-Tecdoc 1220 9-27. 